\title{
Pemberdayaan Usaha Kecil Menengah (UKM) Melalui Implementasi $E$ - Commerce di Kelurahan Tlogomas
}

\author{
Paulus Lucky Tirma Irawan ${ }^{1 *}$, Kestrilia Rega Prilianti ${ }^{1}$ dan Melany ${ }^{1}$ \\ ${ }^{1}$ Universitas Ma Chung, Jl. Villa Puncak Tidar No.1, Doro, Karangwidoro, Kec. Dau, Malang, Jawa Timur, \\ Indonesia, 65151 \\ Email: paulus.lucky@machung.ac.id
}

\begin{abstract}
Abstrak
Usaha Mikro Kecil dan Menengah (UMKM) di Indonesia kini memegang peranan yang cukup penting untuk menggerakkan roda perekonomian negara. Hal ini terutama disebabkan oleh pertumbuhan UMKM yang demikian pesat sehingga membawa dampak positif terhadap perekonomian daerah yang semakin lama semakin dapat menunjukkan kemandiriannya seperti di Kelurahan Tlogomas. Cukup banyak warga Tlogomas yang mempunyai usaha sampingan dalam bentuk UMKM. Sejauh ini pemasarannya terbatas pada tetangga dan teman di sekitarnya. Meskipun telah memanfaatkan media sosial, pertumbuhan UMKM di Tlogomas terbilang lambat. Oleh karena itu, melalui program Ipteks bagi Masyarakat, Universitas Ma Chung telah melakukan pendampingan untuk pembentukan organisasi pengelola UMKM di Tlogomas. Demi mempermudah pengelolaan, dikembangkan pula sebuah media online etlogomas dalam bentuk e-commerce sebagai wadah bagi warga Tlogomas mengembangkan UMKM-nya. Untuk dapat mempertahankan eksistensinya dan terus berkembang secara berkelanjutan, etlogomas masih memerlukan dukungan dalam bentuk pendampingan dan pelatihan baik bagi pengelola e-commerce maupun para warga pemilik UMKM. Oleh karena itu, telah dilaksanakan pula program pendampingan dan pelatihan bagi kelurahan Tlogomas dengan harapan etlogomas dapat menjadi organisasi mandiri yang mampu meningkatkan perekonomian warga Tlogomas.
\end{abstract}

Kata kunci: e-commerce, etlogomas, tlogomas, usaha kecil dan menengah (UKM)

\begin{abstract}
Small and Medium Enterprises (SMEs) in Indonesia now play an important role in driving the country's economy due to the rapid growth of SMEs. This had a positive impact on the regional economy, which has increasingly shown its independence like Tlogomas. The majority of Tlogomas residents run small businesses in the form of SMEs. Its marketing scope is limited to neighbors and friends around it. Despite utilizing social media, the growth of SMEs in Tlogomas is fairly slow. Therefore, through Ipteks bagi Masyarakat Program an e-commerce website has been developed as a media for Tlogomas residents to develop and organize their SMEs. In addition, the official etlogomas organization also has been formed. To be able to maintain its existence and continue to grow sustainably, etlogomas still need assistance and training for both e-commerce managers and SME owners. Therefore, a mentoring and training program for etlogomas was held. Through this program it is hoped that etlogomas will be able to become an independent organization that brings profit and can boost the economy of Tlogomas residents.
\end{abstract}

Keywords: e-commerce, tlogomas, small and medium enterprises (SME)

Format Sitasi: Irawan, P.L.T, Prillianti, K.R. \& Melany. (2020). Pemberdayaan Usaha Kecil Menengah (UKM) Melalui Implementasi E-Commerce di Keluarahan Tlogomas. Jurnal SOLMA, 09(1), 33-44. Doi: http://dx.doi.org/10.29405/solma.v9i1.4347

Diterima: 28 Januari 2020 | Revisi: 27 Maret 2020 | Dipublikasikan: 30 April 2020

(C) 2020 Oleh authors. Lisensi Jurnal Solma, LPPM-Uhamka, Jakarta. Artikel ini bersifat open access yang didistribusikan di bawah syarat dan ketentuan Creative Commons Attribution (CC BY) license. (http://creativecommons.org/licenses/by/4.0/). 


\section{PENDAHULUAN}

Usaha Mikro, Kecil, dan Menengah (UMKM) merupakan kelompok pelaku ekonomi terbesar dalam perekonomian Indonesia dan terbukti menjadi katup pengaman perekonomian nasional dalam masa krisis, serta menjadi dinamisator pertumbuhan ekonomi pasca krisis ekonomi (Sudaryanto \& Wijayanti, 2013; Tedjasuksmana, 2014). Selain menjadi sektor usaha yang paling besar kontribusinya terhadap pembangunan nasional, UMKM juga menciptakan peluang kerja yang cukup besar bagi tenaga kerja dalam negeri, sehingga sangat membantu upaya mengurangi pengangguran (Wijanarko \& Susila, 2016).

Salah satu kunci keberhasilan usaha mikro, kecil dan menengah adalah adalah tersedianya pasar yang jelas bagi produk UMKM disamping promosi, branding, dan minat berwirausaha (Wijanarko \& Susila, 2016). Sementara itu kelemahan mendasar yang dihadapi UMKM dalam bidang pemasaran adalah orientasi pasar rendah, lemah dalam persaingan yang kompleks dan tajam serta tidak memadainya infrastruktur pemasaran (Suci, 2017). Menghadapi mekanisme pasar yang makin terbuka dan kompetitif, penguasaan pasar merupakan prasyarat untuk meningkatkan daya saing (Lestari, Syarief, \& Sumantadinata, 2013; Sedyastuti, 2018). Oleh karena itu, peran pemerintah diperlukan dalam mendorong keberhasilan UMKM untuk memperluas akses pasar melalui pemberian fasilitas teknologi informasi berbasis web yang dapat digunakan sebagai media komunikasi bisnis global (Roosdhani, Wibowo, \& Widiastuti, 2012).

Electronic commerce (e-commerce) merupakan konsep yang bisa digambarkan sebagai proses jual beli barang pada internet atau proses jual beli atau pertukaran produk, jasa, dan informasi melalui jaringan informasi termasuk internet (Turban et al., 2017). Ecommerce setidaknya memberikan enam dampak positif bagi operasi bisnis suatu perusahaan. Keenam dampak tersebut yakni meningkatkan efisiensi, penghematan biaya, memperbaiki kontrol terhadap barang, memperbaiki rantai distribusi (supply chain), membantu perusahaan menjaga hubungan yang lebih baik terhadap pelanggan dan membantu perusahaan dalam menjaga hubungan yang lebih baik terhadap pemasok (supplier) (Yau, 2002). Kalakota, R. dan Whinston (1997) mendefinisikan e-commerce dari beberapa perspektif berikut: 
1. Perspektif komunikasi: e-commerce merupakan pengiriman informasi, produk/layanan, atau pembayaran melalui line telepon, jaringan komputer atau sarana elektronik lainnya.

2. Perspektif Proses Bisnis: e-commerce merupakan aplikasi teknologi menuju otomatisasi transaksi dan aliran kerja perusahaan.

3. Perspektif layanan: $e$-commerce merupakan salah satu alat yang memenuhi keinginan perusahaan, konsumen dan manajemen dalam memangkas biaya layanan ketika meningkatkan mutu barang dan kecepatan pelayanan.

4. Persperktif Online: e-commerce berkaitan dengan kapasitas jual beli produk dan informasi di internet dan jasa online lainnya.

Melalui program pengabdian masyarakat di skim Ipteks bagi Masyarakat (IbM) yang didanai oleh Kemenristekdiki pada tahun 2016, telah dikembangkan fasilitas website bagi Kelurahan Tlogomas untuk menunjang upaya pemasaran produk-produk eco-green seperti biopori yang diproduksi oleh warga Tlogomas.

Namun, pemasaran secara online ini rupanya belum membuahkan hasil yang maksimal. Salah satu akar masalahnya adalah belum adanya koordinasi yang baik dari warga untuk memanfaatkan bersama fasilitas tersebut. Oleh karena itu dipandang perlu untuk membuat organisasi e-commerce sebagai bagian dari strategi bisnis sehingga pengelolaan bersama pemasaran UMKM secara online dapat dilakukan dengan lebih baik (Nurzamzami, Ayatusyifa. Siregar, 2014). Masalah lain yang teridentifikasi adalah SDM di Tlogomas belum dapat mengoperasikan/mengelola website dengan baik meskipun sebelumnya telah dilakukan pelatihan. Akibatnya website tidak terawat dengan baik hingga pada akhirnya warga malas untuk menggunakannya.

Oleh karena itu melalui program pengabdian kepada masyarakat ini telah dilaksanakan program pendampingan dan menghasilkan berdirinya organisasi $e$-commerce yang diresmikan dengan nama etlogomas. Gambar 1 menunjukkan logo resmi organisasi tersebut.

\section{E़ ETLOGOMAS}

Gambar 1. Logo Resmi etlogomas 


\section{MASALAH}

Beberapa masalah yang masih ditemui sejak berdirinya etlogomas adalah personel pengelola organisasi yang terus berubah-ubah dikarenakan kesibukan masing-masing, keterampilan penanganan website masih belum baik sehingga menyebabkan beberapa kali website tidak dapat diakses dan belum ada metode pemasaran yang baik untuk dapat menjaring pelanggan maupun UMKM untuk dapat bergabung dalam etlogomas. Selain itu, dari beberapa UMKM yang telah berjualan melalui etlogomas diketahui bahwa mereka belum memiliki keterampilan yang memadai untuk membuat representasi produk yang menarik.

\section{METODE PELAKSANAAN}

Sebelum pengabdian dilaksanakan, kami membuat terlebih dahulu pengembangan website sebagai berikut:

1. Pertemuan awal dengan warga Tlogomas

Pada acara ini dilakukan diskusi dengan perwakilan warga untuk dapat mengetahui potensi teknologi informasi yang telah ada di wilayah Tlogomas dan juga pemahaman warga tentang e-commerce. Dari diskusi tersebut diketahui bahwasannya warga Tlogomas telah memanfaatkan teknologi informasi dalam bentuk website sebagai penyebaran informasi. Terdapat website resmi dari pemerintah Kota Malang dan sebagai tambahannya terdapat pula website yang dikelola oleh Kelompok Informasi Masyarakat (KIM) Tlogomas. Sebagian besar warga tidak asing dengan media website dan juga sistem jual beli online. Hal ini merupakan peluang yang baik untuk keberlangsungan e-commerce di Tlogomas nantinya. Direncanakan e-commerce yang akan dibangun untuk komersialisasi biopori dilekatkan dengan website yang dikelola oleh KIM. Hal ini untuk menjamin bahwa website e-commerce terawat dengan baik. Selain itu, sistem e-commerce juga akan dikelola oleh KIM dan diharapkan dapat mengkomersialisasikan produk-produk unggulan warga lainnya. Oleh karena itu, akan ditunjuk seorang koordinator yang bertanggungjawab dalam koordinasi para penjual produk.

2. Konsolidasi fitur-fitur website

Dari data yang diperoleh melalui pertemuan awal dengan warga dikembangkan sebuah website e-commerce versi beta (versi draft). Draft website ini kemudian dikonsolidasikan dengan pengurus KIM untuk mendapatkan masukan-masukan sebagai bahan pembenahan selanjutnya. Masukan yang diperlukan antara lain adalah logo yang 
akan digunakan, warna utama sebagai identitas Tlogomas, sistem pembayaran dan pengelompokan produk.

3. Pembenahan sistem

Dari hasil konsolidasi dilakukan kembali penyesuaian-penyesuaian agar website dapat memenuhi kebutuhan warga. Hingga Laporan akhir ini dibuat website masih terus disesuaikan kontennya.

4. Uji coba website

Merupakan tahapan untuk memastikan bahwa website benar-benar layak untuk digunakan dalam jual beli. Pada tahapan ini sekaligus akan dilaksanakan pelatihan untuk pengurus KIM sehingga dapat secara mandiri mengelola e-commerce Tlogomas.

Berdasarkan permasalahan yang dihadapi oleh warga Tlogomas serta target luaran yang akan dicapai maka berikut adalah langkah-langkah yang akan dilakukan dalam kegiatan pengabdian kepada masyarakat untuk implementasi $e$-commerce bagi pengelolaan UMKM di Tlogomas.

Tabel 1. Metode pendekatan berdasarkan permasalahan, solusi, dan target luaran

\begin{tabular}{|c|c|c|}
\hline Permasalahan & Solusi dan Target Luaran & Metode Pendekatan \\
\hline $\begin{array}{l}\text { Keterampilan penanganan } \\
\text { website masih belum baik } \\
\text { sehingga menyebabkan } \\
\text { beberapa kali website tidak } \\
\text { dapat diakses }\end{array}$ & $\begin{array}{l}\text { Menyediakan SDM yang } \\
\text { mempunyai keterampilan yang } \\
\text { baik dalam pengelolaan website } \\
\text { e-commerce }\end{array}$ & 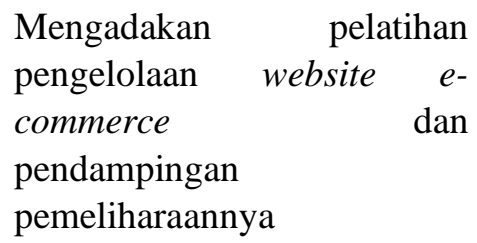 \\
\hline $\begin{array}{l}\text { Pemasaran etlogomas } \\
\text { masih belum baik sehingga } \\
\text { pelanggan maupun penjual } \\
\text { yang bergabung dengan } \\
\text { etlogomas masih sangat } \\
\text { sedikit }\end{array}$ & $\begin{array}{l}\text { Menyediakan media dan strategi } \\
\text { pemasaran yang sesuai sehingga } \\
\text { partisipasi terhadap etlogomas } \\
\text { meningkat }\end{array}$ & $\begin{array}{l}\text { Mengadakan pelatihan dan } \\
\text { pendampingan } r \text { untuk } \\
\text { pembuatan media promosi } \\
\text { dan strategi pemasaran yang } \\
\text { baik }\end{array}$ \\
\hline $\begin{array}{l}\text { Representasi produk dan } \\
\text { desain kemasan produk } \\
\text { yang ada di etlogomas } \\
\text { masih belum baik sehingga } \\
\text { kurang menarik bagi } \\
\text { pembeli }\end{array}$ & 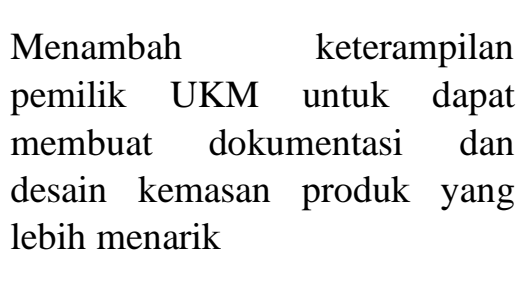 & $\begin{array}{l}\text { Mengadakan pelatihan } \\
\text { dokumentasi produk dan } \\
\text { desain kemasan }\end{array}$ \\
\hline
\end{tabular}

Evaluasi pelaksanaan program pengabdian masyarakat ini dilakukan selama proses pelatihan dan pendampingan. Hal utama yang harus dipantau adalah kesesuaian materi pelatihan dengan keterampilan yang diharapkan dimiliki oleh pengelola etlogomas maupun pemilik UKM. Sedangkan keberlanjutan setelah IbM dilaksanakan dapat dilihat 
dari kemandirian mitra untuk dapat mengelola UKM di Tlogomas melalui website ecommerce yang telah ada. Alur pelaksanaan kegiatan dapat dilihat pada Gambar 2 berikut ini.

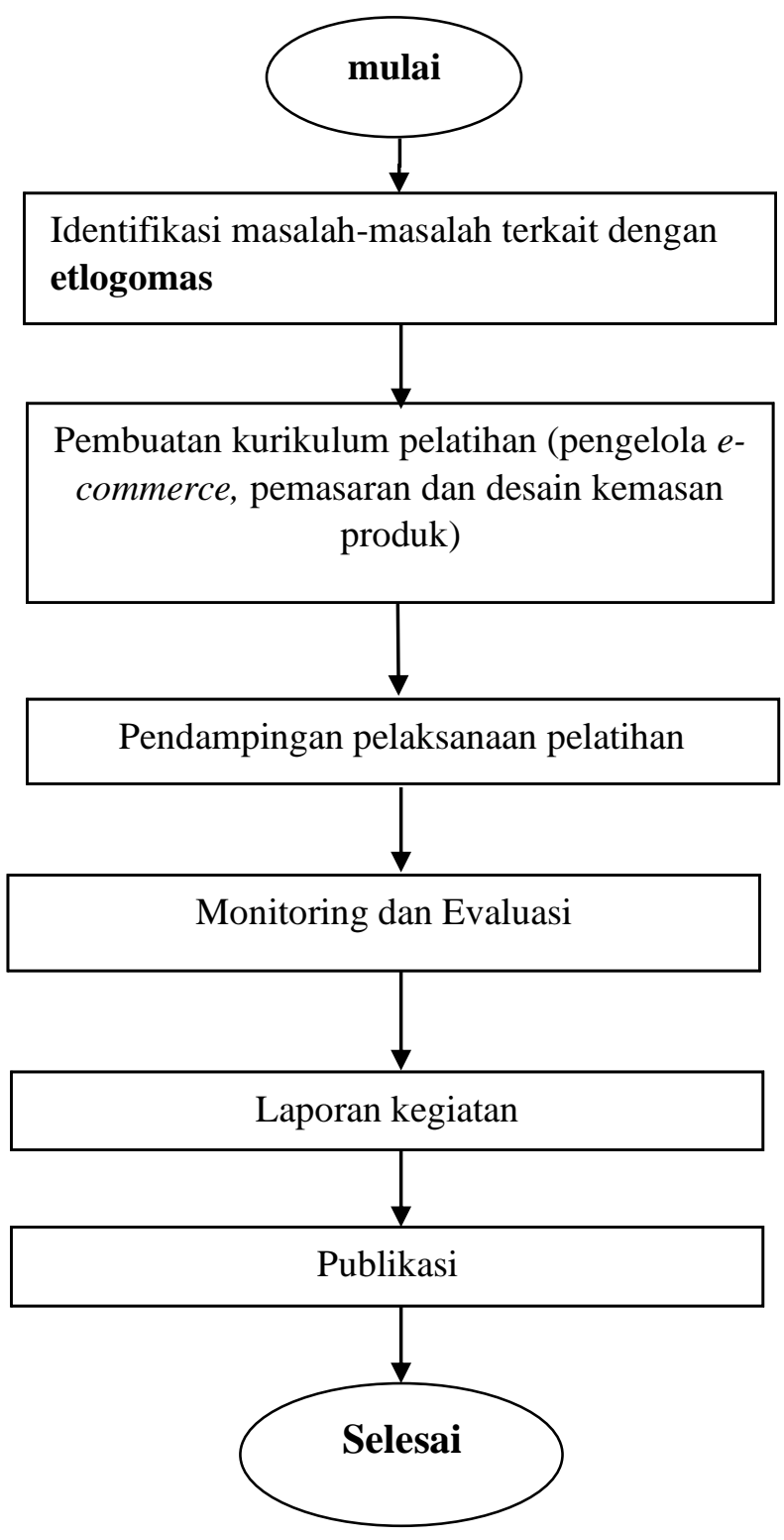

Gambar 2. Tahapan pelaksanaan kegiatan

\section{HASIL DAN PEMBAHASAN}

Hingga akhir program pengabdian masyarakat, telah dilaksanakan sebanyak 3 pelatihan sesuai dengan rencana awal kegiatan. Berikut adalah penjabaran pelaksanaan masing-masing pelatihan: 
1. Pelatihan untuk pengelolaan website etlogomas

Telah dialokasikan satu orang operator website untuk melakukan update, pengelolaan dan maintenance website. Kepada orang tersebutlah diberikan pelatihan untuk penanganan website etlogomas. Pelatihan seperti pada gambar 3 dilaksanakan di Universitas Ma Chung. Hasil pelatihan cukup memuaskan, personel yang ditugaskan menangani website sudah cukup mahir dalam melakukan pengaturan-pengaturan isi website. Namun untuk fitur-fitur utama masih memerlukan bantuan tim Universitas Ma Chung. Dalam proses pelatihan tersebut, website etlogomas sempat mengalami kerusakan dikarenakan kesalahan penanganan dan pengaturan file. Namun kini telah berhasil dikembalikan seperti keadaan semula.

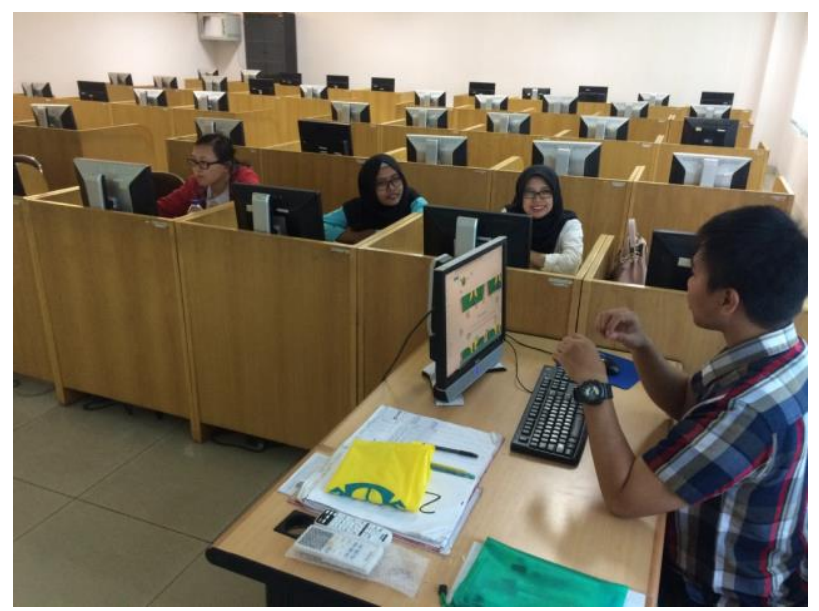

Gambar 3. Suasana Pelatihan Pengelolaan Website etlogomas

2. Pelatihan strategi pemasaran produk secara online

Dilaksanakan dua pelatihan terkait pemasaran online ini. Pelatihan pertama adalah pemanfaatan Google My Business dan yang kedua adalah penggunaan Imooji.

a) Google My Business

Google My Business adalah sebuah tool yang disediakan oleh Google untuk membantu sebuah bisnis mendapat listingan Google secara gratis. Listingan ini akan muncul saat orang-orang mencari bisnis kita atau bisnis di bidang yang sama di mesin penelusur dan Google Maps. Fasilitas ini dapat membantu pemilik bisnis membuat dan memperbaharui listingan agar calon pelanggan bisa menemukan bisnis tersebut secara online dengan mudah (UPB, 2019). Dengan demikian aksesibilitas etlogomas secara otomatis juga akan meningkat jika setiap pemilik UMKM yang tergabung dalam etlogomas dapat membuat tokonya mudah ditemukan secara 
online. Aksesibilitas layanan web e-commerce yang baik memberikan pengaruh besar terhadap persentase penjualan yang dilakukan secara online (Alhasanah, Kertahadi, \& Riyadi, 2014; Aryadita, Widyastuti, \& Wardani, 2017). Sejumlah 25 peserta mengikuti pelatihan ini. Kebanyakan dari mereka adalah warga pemilik UMKM dan juga anggota karang taruna. Pada pelatihan ini setiap peserta menerapkan langsung pembuatan profil UMKM nya masing-masing dengan Google My Business. Gambar 4 adalah dokumentasi pada saat pelatihan dan Gambar 5 adalah contoh hasil pengaturan profil melalui Google My Business.

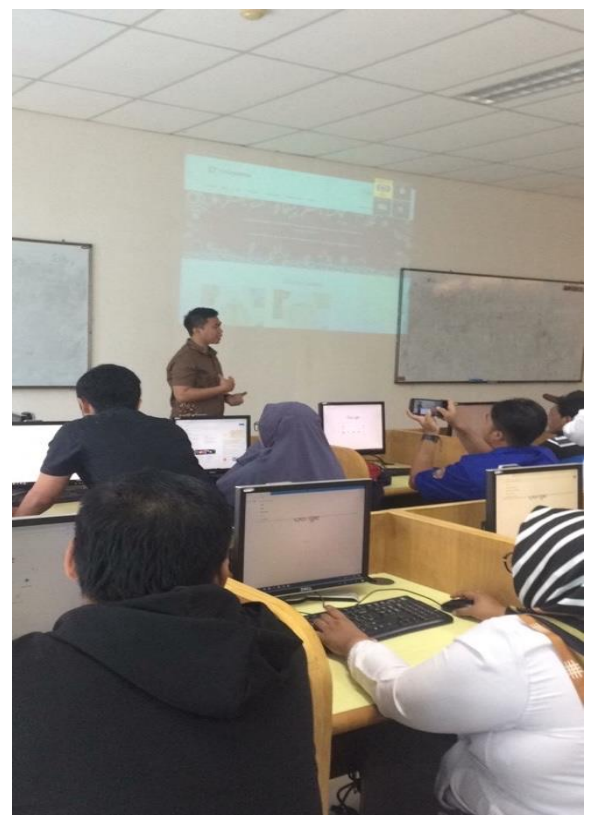

Gambar 4. Pelatihan Google My Business

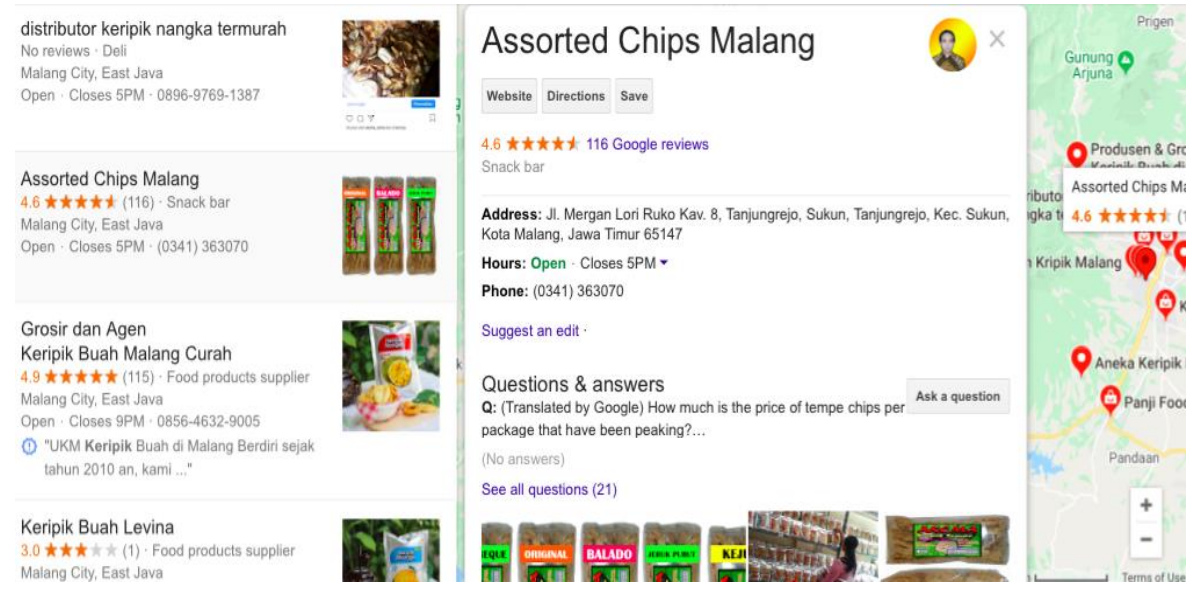

Gambar 5. Hasil Pengaturan Profil UMKM dengan Google My Business 


\section{b) Imooji}

Imooji adalah salah satu sarana online yang dapat diakses melalui situs imooji.co.id dapat digunakan untuk membuat interaktif digital brosur, katalog produk, undangan event, promosi barang atau jasa, greeting cards, dan banyak kegunaan lainnya. Layanan Imooji dapat digunakan untuk membantu para pemula bisnis dalam memasarkan produknya. Beberapa fitur keunggulan yang ditawarkan oleh situs Imooji ini adalah Smart-phone friendly, Easy to make, Click Call to Action dan Easy to Share dimana seluruh kendali terdapat di smart-phone (menggunakan smartphone). Disamping itu, Imooji dapat digunakan untuk keperluan membuat brosur, dengan platform berbasis web ini pengguna juga bisa membuat katalog produk, undangan event, promosi barang atau jasa, hingga kartu ucapan selamat.
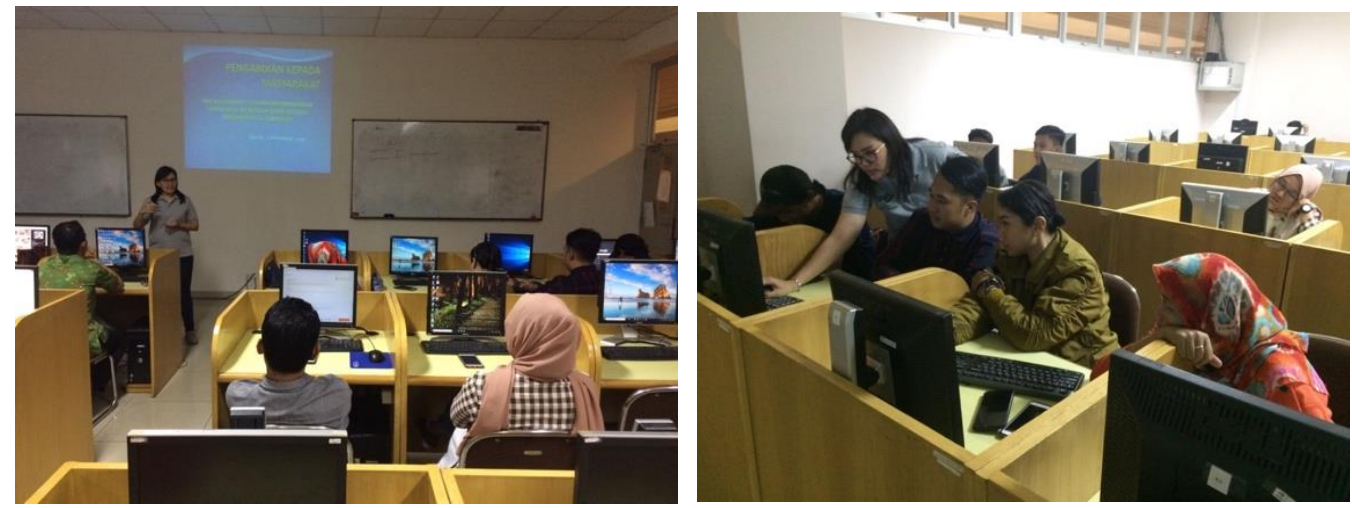

Gambar 6. Suasana Pelatihan Imooji

Sehubungan dengan adanya kebutuhan pemasaran digital bagi e-commerce di lingkungan Kelurahan Tlogomas, maka pada tanggal 1 November 2019 pelatihan imooji diselenggarakan. Hal ini sangat bermanfaat khususnya bagi pelaku usaha industri kecil dan menengah (IKM) yang baru saja melakukan start-up untuk bisnisnya. Beragam bisnis terdapat pada E-Commerce Tlogomas mulai dari makanan, pakaian, sepatu hingga produk jasa lainnya (laundry, sewa mobil, tour and travel). Gambar 6 menunjukkan suasana saat berlangsungnya pelatihan Imooji.

Diharapkan kegiatan ini memberikan manfaat langsung dan dapat digunakan dalam proses pemasaran produk dalam E-commerce Tlogomas sehingga layanan jual beli dalam situs online tersebut dapat memberikan manfaat maksimal kepada seluruh pelaku usaha. 
3. Pelatihan dokumentasi produk

Pelatihan ini ditujukan untuk memberi keterampilan kepada para pemilik UMKM untuk membuat dokumentasi produk yang baik dan layak jual. Dengan media digital, pembuatan media promosi yang bagus menjadi lebih mudah, namun tanpa didukung dengan foto produk yang baik tentu nilai jual produk tidaklah maksimal. Gambar 7 menunjukkan suasana pelatihan foto produk. Para pemilik UMKM diajarkan trik bagaimana membuat foto sekelas studio dengan fasilitas sederhana di rumah dan kamera smartphone. Kuncinya adalah pada pemilihan background dan pencahayaan yang memadai. Kualitas kamera smartphone saat ini pada umumnya sudah sangat memadai untuk bisa membuat foto produk yang cukup bagus. Beberapa arahan terkait dengan dasar-dasar fotografi juga diberikan dalam kesempatan tersebut. Peserta juga diberi waktu untuk praktek memfoto produk UMKM yang dibawanya serta diunggah untuk digunakan sebagai brosur yang dibuat dengan Imooji.

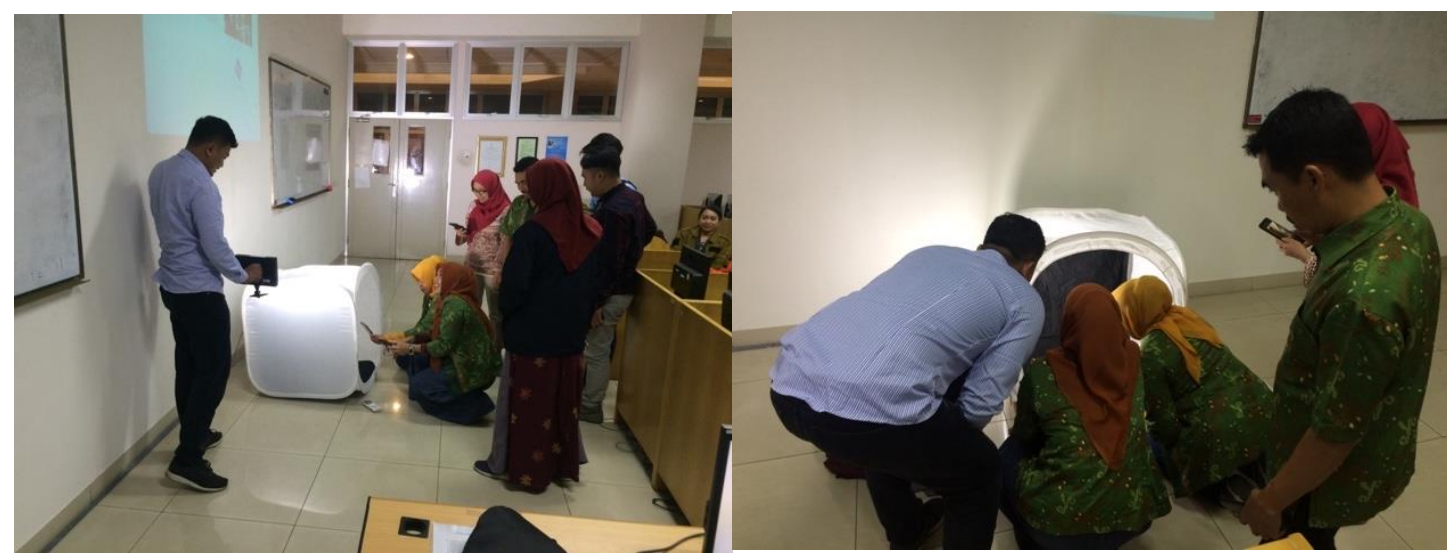

Gambar 7. Suasana Pelatihan Foto Produk

\section{KESIMPULAN}

Secara umum seluruh kegiatan pada pengabdian masyarakat di Kelurahan Tlogomas berjalan dengan baik dan sesuai dengan rencana yang sudah disepakati oleh kedua belah pihak. Program ini juga mendapat dukungan resmi dari Kelurahan Tlogomas dan disambut dengan antusiasme yang positif oleh warga. Selain itu, pihak Kelurahan Tlogomas juga turut mengajukan program etlogomas ini sebagai salah satu bentuk kegiatan dalam program kerja serta inovasi dari Kelurahan. Hal ini menunjukkan bahwa fokus kegiatan pengabdian masyarakan yang sudah dilakukan diakui dan dapat dimanfaatkan secara optimal oleh Kelurahan Tlogomas. 


\section{UCAPAN TERIMA KASIH}

Terima kasih diucapkan kepada Lembaga Penelitian dan Pengabdian Masyarakat Universitas Ma Chung yang sudah memungkinkan kegiatan pengabdian kepada masyarakat ini dapat diselenggarakan dengan baik dan kelurahan Tlogomas yang sudah berkenan turut berpartisipasi aktif dalam kegiatan pengabdian ini.

\section{DAFTAR PUSTAKA}

Alhasanah, J. U., Kertahadi, \& Riyadi. (2014). Pengaruh Kegunaan, Kualitas Informasi dan Kualitas Interaksi Layanan Web E-Commerce terhadap Keputusan Pembelian Online (Survei pada Konsumen www.getscoop.com). Jurnal Administrasi Bisnis, 15(2), 1-10.

Aryadita, H., Widyastuti, D. A., \& Wardani, N. H. (2017). Analisis Kualitas Layanan Website E-Commerce Terhadap Kepuasan Pengguna Menggunakan Metode Webqual 4.0. Jurnal Sistem Informasi, 10(1), 29-35. https://doi.org/10.15408/sijsi.v10i1.7747

Kalakota, R. dan Whinston, A. B. (1997). Electronic commerce: a manager's guide. Addison-Wesley Professional.

Lestari, W., Syarief, R., \& Sumantadinata, K. (2013). Strategi Peningkatan Daya Saing Kakao Indonesia Di Pasar Internasional. Manajemen IKM, 8(1), 35-44. https://doi.org/10.1016/S0960-8524(03)00155-X

Nurzamzami, Ayatusyifa. Siregar, E. H. (2014). Peningkatan Daya Saing UMKM Alas Kaki di Kecamatan Ciomas, Kabupaten Bogor dan Implikasinya terhadap Strategi Pemasaran. Jurnal Manajemen Dan Organisasi, 5(1), 15-29. Retrieved from http://journal.ipb.ac.id/index.php/jmo/article/view/12127

Roosdhani, M. R., Wibowo, P. A., \& Widiastuti, A. (2012). Analisis Tingkat penggunaan Teknologi Informasi dan komunikasi pada Usaha Kecil Menengah di Kab. Jepara. Jurnal Dinamika Ekonomi Dan Bisnis, 9(2), 89-104.

Sedyastuti, K. (2018). Analisis Pemberdayaan UMKM Dan Peningkatan Daya Saing Dalam Kancah Pasar Global. INOBIS: Jurnal Inovasi Bisnis Dan Manajemen Indonesia, 2(1), 117-127. https://doi.org/10.31842/jurnal-inobis.v2i1.65

Suci, Y. R. (2017). Perkembangan UMKM (Usaha Mikro Kecil Menengah) di Indonesia. Jurnal Ilmiah Cano Ekonomos, 6(1), 51-58.

Sudaryanto, R., \& Wijayanti, R. R. (2013). Strategi pemberdayaan UMKM menghadapi pasar bebas Asean. Pusat Kebijakan Ekonomi Makro. Jakarta: Badan Kebijakan Fiskal, Kementerian Keuangan.

Tedjasuksmana, B. (2014). Potret Umkm Indonesia Menghadapi Masyarakat Ekonomi ASEAN2015. In The 7th NCFB and Doctoral Colloquium 2014.

Turban, E., Outland, J., King, D., Lee, J. K., Liang, T. P., \& Turban, D. C. (2017). Electronic commerce 2018: a managerial and social networks perspective. Springe.

UPB, J. (2019). UMKM Pembinaan Usaha Mikro Kecil Dan Menengah Menggunakan 
Google My Business. Jurnal Pengabdian Barelang, 1(01), 5-7.

Wijanarko, A., \& Susila, I. (2016). Faktor Kunci Keberhasilan UMKM Kreatif. Perubahan Kultur Dan Sinergitas Bisnis. Sidoarjo: FEB Universitas Muhammadiyah Sidoarjo.

Yau, O. (2002). An Empirical Investigation of the Impact of Business-to-business Electronic Commerce Adoption on the Business Operations of Hong Kong Manufacturers. First Monday, 7(9). 